\title{
Design of information systems as an aid to migrants
}

\section{Hernández-Navarro, Patricia.}

Universidad Iberoamericana Ciudad de México.patyhernandez1523@hotmail.com.

\begin{abstract}
Starting from the official call for the $1^{\text {st }}$ Contest "Let us help those who aid migrants", by the International Committee of the Red Cross and the Universidad Iberoamericana's Program on Migration, students of the degree course on Graphic Design and an interdisciplinary group of teacher developed a "Visual communication system to promote hygiene and health in hostels lodging migrants in transit."
\end{abstract}

This teachers' group, through the use of a dialectical - reflexive methodology (Diezt, 2011) was able to analyze the social processes endured by migrants and solve their problems by applying design, using as main tool the discussion and opinion confrontation among those involved in the job in order to develop a common language for the participants in the design process coming from different disciplines, taking into account the relationship between sign and images' comprehension by users.

This paper objective is to share a teaching - learning experience by way of a case study and it shows the importance of using new tools and the feasibility of integrating different disciplines in projects with a social motivation.

The present document will develop along three main axes:

1. Situation diagnosis. The project starts questioning: Which factors must be considered in order to get satisfactory results from a design project with a social aim? Due to user's complexity, it is required an interdisciplinary approach in order to know him, so that an adequate graphic solution can be provided.

2. Systems and tools development. This section includes the description of the strategy to follow for the design carrying out, research, implementation, modification, installation and setting methods. Also, it answer to the question: Why is it important to utilize the new social tools in design processes?

3. Results and evaluation. The document ends presenting answers to: Which ones and in which way were the etnometodological tools incorporated into the project?

Keywords: Systems, design, social, interdisciplinary, migrant 


\section{Situation diagnosis}

From the 90's on, the academic members of the Universidad Iberoamericana (UIA) were fully aware of the significance of forming social researchers committed and acquainted with the needs of the users for which they design. Even though the process of change and acceptance of the compromise implies grater rigorousness in the students preparation, the Design Department undertook the challenge and now its professors are totally accountable to the society. In this regard, a professional profile according new needs was generated which favor the preparation of designers more conscious of their environment and apt to overcome the work challenges imposed by users seeking a higher level of life quality and well-being.

It is for these reasons that, when we were invited to take part in the Red Cross Contest above mentioned, UIA's students and teachers as well wholeheartedly accepted the challenge of producing a proposal to get optimum results but, due to the case complexity, it was clear that new theoretical - methodological approaches were needed, taking into account the interdisciplinary and multicultural links to be established with the users.

The subject of study was migrants travelling through México toward United States of America (USA). They have a precarious economy and most of them are illiterate. Besides, they confront serious health risks like dehidratation, gastrointestinal, respiratory, urinary or cutaneous infections, grievous bodily injuries or insect and viper bites, among others. And without concern for their genre, age or origin, they are constantly abused by delincuential groups and even by certain local authorities and have to undergo public policies that try to impede their passage and violate their human rights.

Along their transit through our national territory, they find 55 hostels, which are gray and lifeless spaces, lodging from 20 to 400 people, for 24 to 48 hours. This population is composed of $4 \%$ children, $11 \%$ women and $85 \%$ men. The majority of them (60\%) proceed from Honduras, followed by individuals from Nicaragua, Costa Rica, Panama, Guatemala, Belice and Etiopía. This information was supplied by the institutions sponsoring the contest by the Universidad Iberoamericana's Program on Migration in the initial meeting of the project on September $11^{\text {th }}, 2013$.

These data were essential in establishing one of the main parameters for hygiene promotion, a concept defined as: "a planned and systematic strategy allowing people to carry the necessary actions on to prevent or limit risks of diseases related to water, sanitary conditions and hygiene" (Sphere Project, 2016). 


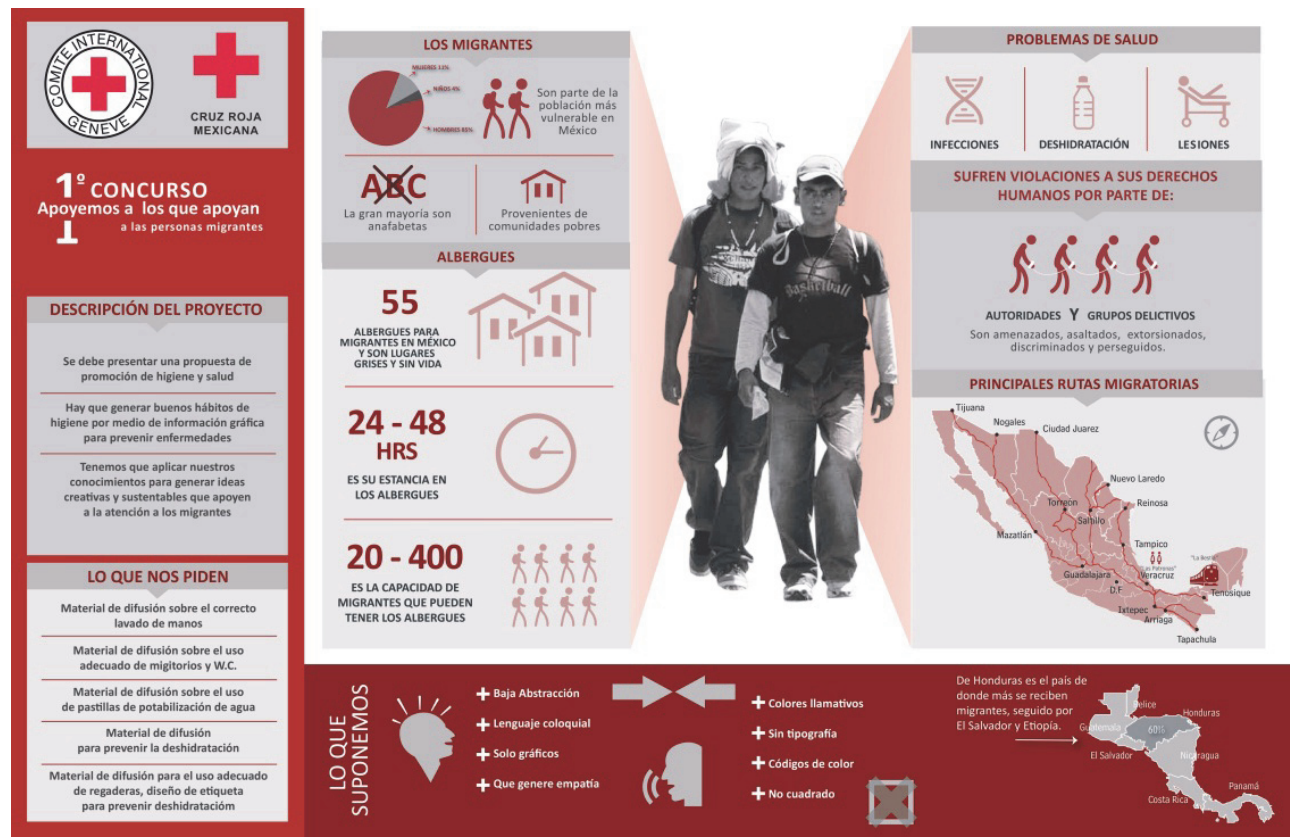

Fig. 1 "Infographic contest "Let us help those who aid migrants". Created by the pupil Paulette Ordoñez.

\section{Systems and tools development}

Creative processes of visual communication enable us to devise elements to favor the correct transmission of a problem's terms in a social environment and facilitate its solution by promoting a change in the behavior of those affected. As María Ledesma tell us: a design will generate any of three different types of attitude in the user: "To do - To read, To do - To know, To do - To perform" (Ledesma, 1997), where the designer function is to create elements for the easy transmission of a message, in this case, by informative cells synthesizing a long and may be complex massage, in order to obtain a favorable response. So, the designer shall focalize on the people for whom he will create in such a manner that his graphic elements are capable of modify their behavior.

However, how can this goal be achieved in a project with a social approach, when it implies that the student must directly work on an extreme situation, by far alien to his own life style? It is here that interdisciplinarity comes up as a helpful approach to get a first approximation to users' universe, allowing the designer to grasp that alternative reality. The interdisciplinary group of teachers was integrated by: the Master Sciences in Social Anthropology Tatiana Elizabeth Lara San Luis, the Political and Social Sciences Doctor Javier Urbano Reyes, the Engineer Alejandro Vergara Frutos and the Master Sciences in Education and Industrial Designer Patricia Hernández Navarro.

Anthropology has mechanisms that enable him to focus his attention on the user's observable needs, through the analysis, detection and generation of findings that are useful in conceptualizing creative elements to connect with the user. And from Social Anthropology derives Visual Ethnography, a tool selected for this project because it allows to be near the subject under study without being in its immediate physical vicinity, which is a most convenient option due consideration given to distance and lack of time and safety. The last feature incorporated into the process was visual communication, because it makes possible to establish the relationships between emmisor, message meaning and receptor, taking into account this last one skills and characteristics. 
Main project's objective was to develop a pictograms system permitting the transmission of information related to hygiene promotion (information supplied by the UIA and PRAMI), its convenience and the procedures to follow, trying to change certain inconvenient behaviors of the migrants in the refuges they are received. Regarding its specific targets, they shall, by an adequate design and iconicity and creating the necessary drawing reticules, production and dummies for each one, to originate a system of informative cells that make the users understand, in a clear and efficient way, what actions they are expected to perform, motivating them to comply.

\subsection{Work method}

Already defined the points previously dealt with, we proceeded to conform work teams in accordance with the official announcement, requiring from three to five participants, supervised by an academic adviser, and registered them by e-mail. The Master Sciences in Social Anthropology, Tatiana Elizabeth Lara San Luis, a UIA's teacher of the subject, joined the project from the beginning in order to present to the students and incorporate into the research process the new instruments for remote observation. The interdisciplinary method involving Social Anthropology and Graphic Design was thus promoted.

Once they had the research results, the students recognized a specific set of problems related to the needs of the final users of the design, in which graphic language is most important in communicating the message. Accordingly, they set three main features to be considered in the process of designing, corresponding to its analysis regarding semantical, syntactical and pragmatical aspects, that is: with relation to the understanding of its meaning and representation, regarding its own structure and finally, concerning the relationship between meaning and interpretation.

The creative process brought out multiple options in shape, color and degree of abstraction, so a close filtration based on the research results was implemented. The graphic elements selected were those comprised in the figurative group of analogical motivation "representing the graphic denotation or depiction of a real subject, known within the environment in which it will be used, that could have the likeness of a human being, an object or an animal. This image is consequently of the iconic type and receives the name of pictogram.” (Morris, 1982).

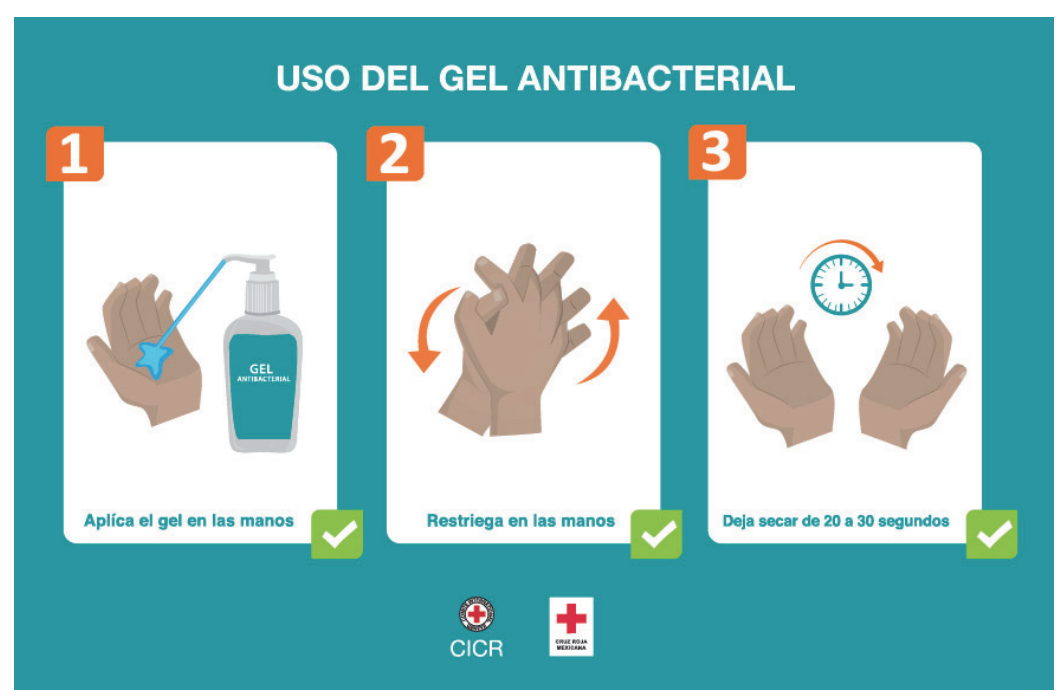

Fig. 2 Cells for promotion and hygiene. Morris (1982). 
There were various difficulties in the graphic conceptualization process. For example, the skin color shade to be utilized, taking into account that the migrant population is multicultural and, were it too clear, the user would not identify himself with it. However, the selection of a blue background was a success, due that it gives idea of calm, and the hostels' guests are subject to a high level of stress at the time of their pass through them.

The same process was performed to select texts because, although the greater part of the migrants are illiterate, it was unavoidable to employ an universal language in which the words utilized had the same meaning for all the users not whistanding their origin, it was necessary to change: "lavarse (wash)" by "restregarse (scrub)", "mingitorios" by "urinales", "w.c." by "sanitarios", among others. The regional representatives of the users supplied us with timely observations that were utilized to make modifications and apply to the design what Umberto Eco calls pertinent aspects (Eco, 1974) for the proper understanding and interpretation of the images' message, which could not convey to the receptor the idea of the person who created it. Through this concept, the students were confirmed in the need to know the users in order to developed clear, functional and empathetic pictograms capable of transmitting the desired idea.
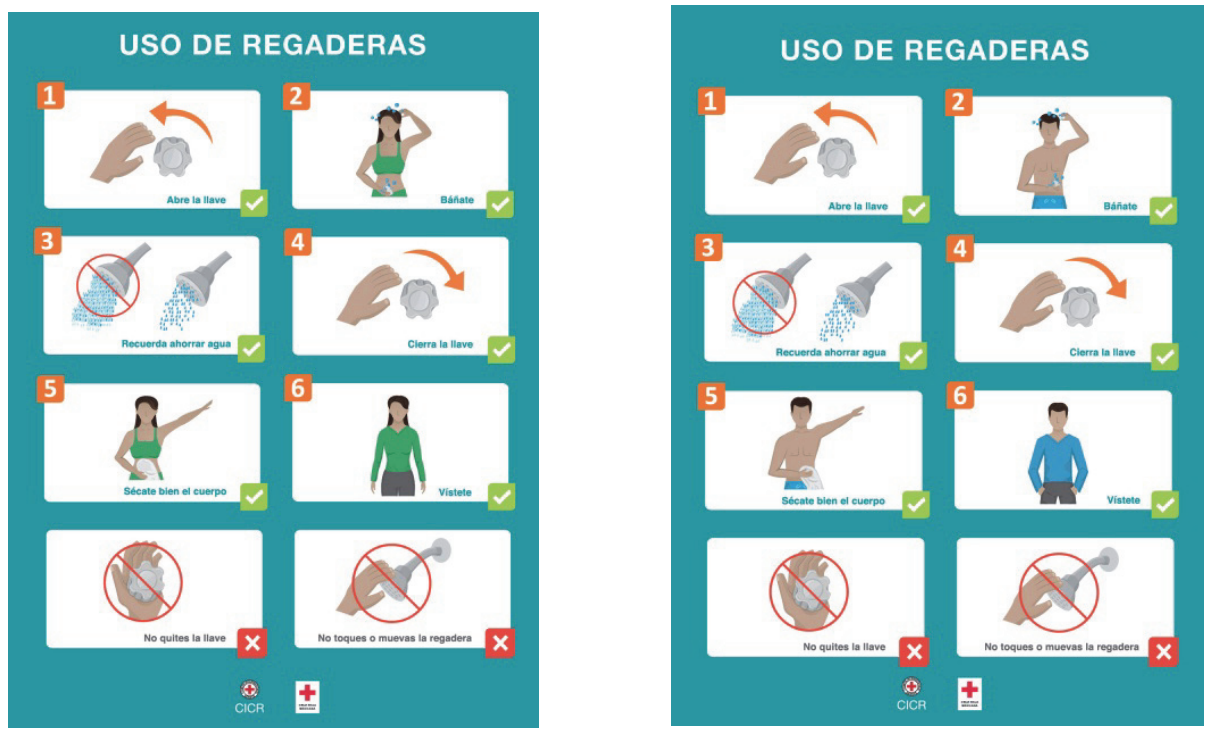

Fig. 3 Cells for promotion and hygiene. Morris (1982)

Once selected the main pictogram representing the migrant, a set of parameters was specified in order to create an homogeneous system, designing a family of images, an standard format and size and the application of the adequate color palette, making always the proper use of the iconicity and clearly promoting the actions represented in the cells. With the design approved, we defined materials and manufacturing and fastening methods and made the mechanical originals for their production and, wishing to have a complete visualization of the project, we generated photos in situ, dummies and renders of each piece, to give a clear idea of their position and function in the hostels.

For the final evaluation of each work team project, the students presented the information obtained in the research phase and submitted a document and infography to the sponsor institutions representatives, who acted as qualifying judges. The documentation submitted included: a) Letter with the names of the students integrating the work team and their academic adviser. b) Research on the migrants and its results. 
c) Design of informative cells for the diffusion of the correct way to wash one's hands and the use of antibacterial gel, use of pills to make water drinkable, prevention of dehydration, labels for water bottles and bags, correct use of urinals, toilets and showers (printed and in compact disk, with all the designs). d) Letter of rights' cession for use, diffusion, exhibition, communication, spreading and reproduction.

They made observations on each report, which were most valuable for the students because, being a real project, they could defend their work, interacting directly with their "customer" and having in advance an experience they will confront in their professional life. The highest authorities of the Committee of International the Red Cross and the Universidad Iberoamericana's Program on Migration, and the Design Department were present in the awards ceremony and the award's certificates were handled the UIA's Rector, Dr. José Morales Orozco, S. J. The winner of the informative cells was the team formed by the students: Paulette Ordóñez, Mariana Nava, Violeta Corona and Lorenza Moctezuma, while the prize corresponding to water labels and illustrative posters was accorded to the team integrated by: Ximena Torres, Ana Sofía Morales, Sofía Arana and Victoria Cojab.

\section{Evaluation and results}

Although there are many linked projects in the Design Department of the Universidad Iberoamericana, there are few cases like this one in which a punctual tracking of the results obtained in the final phase of the project has been done and in which, only six months after being applied extremely favorable outcome is reported. In words of the Ing. Alejandro Vergara Frutos, head of Water and Habitat Projects of the International Committee of the Red Cross, Regional Delegation for Mexico, Central America and Cuba: "In the middle of 2014 and beginning of 2015, they implemented a campaign to promote hygiene in nine hostels offering assistance to migrants in Mexico, five mobile clinics of the Mexican Red Cross and a number of shelters in Honduras. This campaign has two components: 1. A visual part allowing the migrant to follow instructions to improve his hygienic habits. Said posters have been affixed in showers, w.c., wash-hands basins and urinals in the sanitary areas of the hostels" (Vergara, 2015).
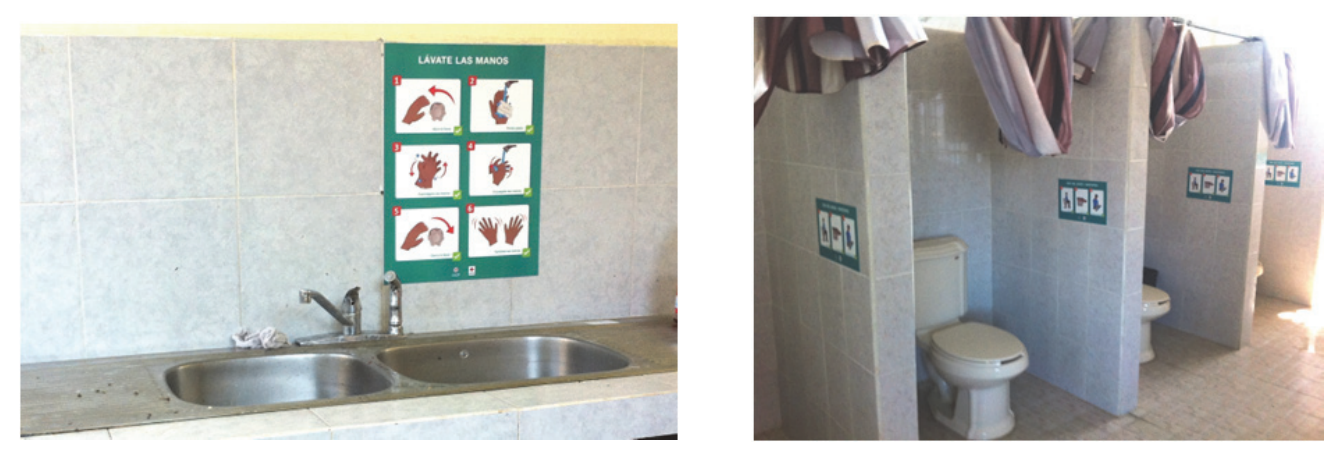

Fig. 4 Cells in hostels offering assistance to migrants in Mexico. Vergara (2015)

One of the benefits that were not expected on the initial objectives having a significant impact has been its use through visual communication systems to encourage healthy practices in meetings with people temporarily housing in refuges. The graphic presentation has been useful as an aid to facilitate each of the cleaning procedures. Using the same posters fixed in the sanitary areas, with the complement of the $\mathrm{s}$ - cycle diagram, it is possible to induce the migrants to change, improve or reinforce their hygienic 
habits. These talks are given by previously formed volunteers from the hostels and by Mexican Red Cross personnel.

Campaign results are encouraging: gastrointestinal diseases product of poor cleaning usages have decreased by various percent points, still there are no official figures published and these are the only information references we have. Common areas are respected and are maintained in better conditions, as evidenced by the following phrases taken from a CICR responsible report: The campaign has been favorably accepted by the migrants and who themselves emphasizes the importance of hygiene to keep people healthy and living together in good terms.
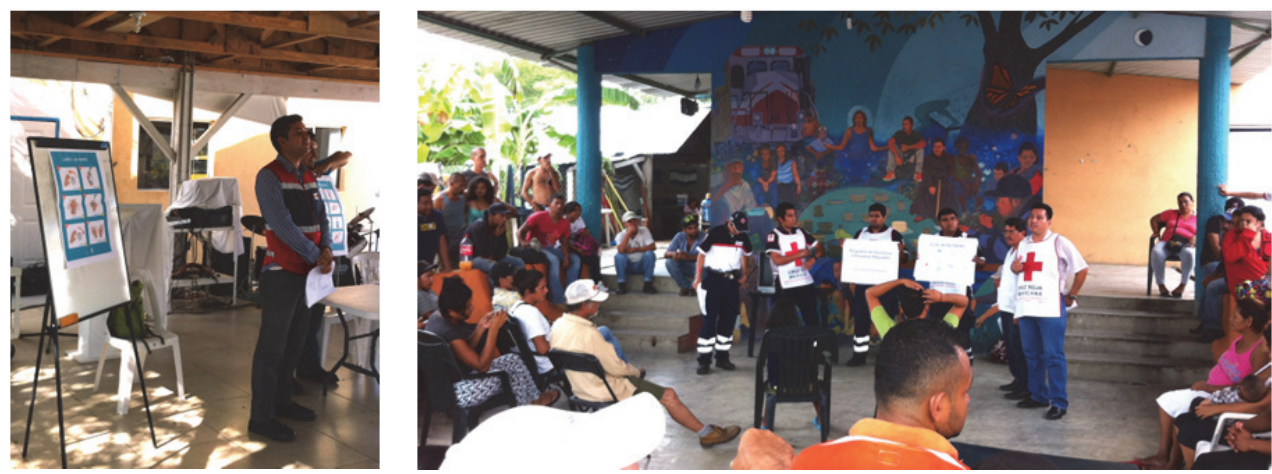

Fig. 4 Talks are given by previously formed volunteers from the hostels and by Mexican Red Cross personnel.

The methodology used, consisting in maintaining a dialog and reflecting together both disciplines, as well as the incorporation of etnomethodological tools generated three main features:

1. It opened the opportunity to create new didactics to teach user centered projects, in which everyone contributes specific elements of his or her area, to produce adequate solutions focused in the social environment. This project results show that the new interdisciplinary model have a positive impact to generate graphic solutions with impact.

2. Finding a work and communication dynamic was not easy. However, the involvement of designers in formation, specialists and academics proved that it is possible to establish integral-learning models, in which by means of rigorously established processes, inclusive solutions can be generated in order to modify erroneous behaviors, so as to improve life quality. As the student Paulette Ordoñez says: "In the research process, Anthropology gave me clarity and understanding about situations to which the migrants are exposed. An interesting aspect was to substitute the phases accompanying figures for ones more uneatable to them, what made me reflect that even though we speak the same language, we give the words a different meaning."

3. The student's rapprochement to social projects far away from their everyday experience results in a better learning and in compromise with those who have less. The experiences had by the work teams along the contest development generated a deep reflex ion about the importance that our discipline worked for the collective improvement. We, the academics, shall propitiate the creation of a social conscience in order that the students develop a critical thinking and have a bearing on changes favorable to our society. As Norberto Chavez says: "The politicization processes should not be understood as marginal, capricious processes, alien to academic matters, but as processes consubstantial with the civic conscience of the university population". 
Finally, we can conclude that, in generating solutions based on the "Design of information systems as an aid to migrants", we were enabled to innovate with a graphic language capable of communicate and connect with the user. In enclosing interdisciplinary and the use of tools like Visual Ethnography, we propitiated observation and detection of the incentives for people to behave in their own benefit. From the results obtained till now, we can rename the project as: "Systems that save lives".

\section{References}

ARFUCH, L., CHAVEZ N., LEDESMA, M., (1997). “Diseño Gráfico ¿un orden necesario?” en Arfuch, L., Chavez N., Ledesma, M., Diseño y comunicación. Buenos Aires: Paidós, p. 40 - 67.

CHAVES, N. (2002). El oficio de diseñar : propuesta a la conciencia crítica de los que comienzan. Barcelona: Gustavo Gili.

CRM, CICR (2014). “Acción y resultados diciembre 2013-mayo 2014”

$<$ http://www.crmsv.org/documentos/CICR\%20\%20Actividades\%20de\%20asistencia\%202014.pdf> [Consulted on April, 2016] [unrecognized author].

DE LA TORRE G. (2000). El lenguaje de los símbolos gráficos. Introducción a la comunicación visual. México: Noriega Editores.

DIEZT, G., (2011). "Hacia una Etnografía doblemente reflexiva: una propuesta desde la Antropología de la interculturalidad" en la Revista de Antropología Iberoamericana, Vol. 8, º1, January-April, , p. 3-26.

ECO U. (1974). Estructura ausente. Introducción a la semiótica. Barcelona: Lumen.

GHASARIAN C. (2008). "La reflexivilidad" en Ghasarian C. De la Etnografía a la Antropología Reflexiva". Argentina: Editorial del Sol. p. 17-22.

GUÍA DE PROYECTO DE ASISTENCIA A PERSONAS MIGRANTES. PROMOCIÓN DE HIGIENE. (2014). CICR. México. Publicación interna.

HABERMAS, J. (2004). Teoría de acción comunicativa. Madrid: Taurus.

HERNÁNDEZ NAVARRO, P. y LARA SAN LUIS T. (2015). "La interdisciplinariedad como propuesta para el diseño incluyente a partir del uso de herramientas etnometodológicas. Estudio de caso." En MX DESIGN CONFERENCE 2015. Diseño Incluyente Universal. Ciudad de México. Publicación en proceso.

HERNÁNDEZ NAVARRO, P. y ROJAS MORALES M. (2015). "Diseñando para la acción y el bienestar." En Coloquio Internacional de Diseño Forma 2015. Diseño con Sentido. La Habana Cuba. ISBN: 9789597182146.

SIN EMBARGO.MX. (2016) Alumnos de la Ibero apoyarán a albergues de migrantes $<$ http://www.sinembargo.mx/25-10-2013/795222> [Consulted on May 1º, 2016] [unrecognized author].

MORRIS, C. (1985). Foundations of the Theory of Signs. Barcelona: Ediciones Paidós.

TAPIA, A. (2007). El diseño gráfico en el espacio social. México: Designio.

THE SPHERE PROJECT. (2010). “Humanitarian Charter and Minimum Standards in Humanitarian Response. Hygiene promotion." <http://www.spherehandbook.org/en/hygiene-promotion/> [Consulted on April, 2016].

UNICEF. (2010). “Agua, saneamiento y promoción de higiene IFRC” Promoción de higiene $<$ www.unicef.org/spanish/wash/index_43107.html> [Consulted on April, 2016] [unrecognized author]. 